\title{
Validation of an Analytical Method using GC-FID to Determine the Ethanol in Palmyrah Alcoholic Beverages
}

\author{
${ }^{1}$ A. Kirushanthi, ${ }^{2}$ S. Srivijeindran \\ ${ }^{1}$ Research Assistant, High-Tech Laboratory, Palmyrah Research Institute, Northern Province, Sri Lanka \\ ${ }^{2}$ Manager, Applied Research and Quality control, Palmyrah Research Institute, Northern Province, Sri Lanka
}

\begin{abstract}
Palmyrah (Borassus Flabellifer. L) Sap is extracted from female/ male inflorescence of Palmyra palm. The fermented palm sap referred to as 'Toddy' which is a mild alcoholic beverage. Fermentation is done almost immediately by a group of heterogeneous microorganisms. Palmyrah toddy is distilled to produce the alcoholic liquors like palm wine, arrack. The aim of this study is to develop and validate gas chromatographic method for the determination of ethanol content in palmyrah based alcoholic products. Palmyrah toddy was collected from different Palmyrah societies located in Chavakachcheri, Karaveddi and Kondavil, Jaffna while Palmyrah arrack was obtained from Varany distillery respectively. The developed method was validated for various parameters such as linearity, accuracy, precision, limit of detection, and limit of quantification. The method linearity was found to be high with good correlation coefficient values $(R 2=0.999)$. From the data of validation criteria it is suggested that the method is suitable for the determination and for the quality identification of ethanol in Palmyrah based alcoholic products.
\end{abstract}

Keywords: Ethanol, Arrack, Toddy, Gas chromatography, Palmyrah.

\section{INTRODUCTION}

Currently, Palmyrah toddy and arrack are alcoholic beverages of Northern Sri Lanka and other palmyrah growing countries [1]. Plamyrah toddy is produced by fermentation of palmyrah sap while arrack is produced either by pot still or column distillation of Palmyrah toddy [2,3]. There is huge demand to both alcoholic beverages in the local and foreign market as they are $100 \%$ natural and their health benefits. Ethanol content is very important for the mouth-feel and flavor of alcoholic beverages [4]. Ethanol content of an alcoholic beverage determines the quality index as well as taxation factor. Palmyrah alcoholic beverages are exported by the local agencies of Sri Lanka recently. Determination of ethanol content in beverages will aid to ease their marketing process. Also ethanol content is needed as the standard method of quality control for beverage manufacturers. Hence, a simple, accurate, precise and cost effective method should be develop to determine the ethanol content of Palmyrah alcoholic beverages.

Ethanol, together with water and carbohydrates, is one of the main components of alcoholic beverages. Many methods have been reported for ethanol determination. These methods are essentially based on the following techniques: (i) distillation followed by physical or chemical measurements, (ii) chromatography, (iii) infrared spectrometry, (iv) enzyme methods, and (v) flow injection. Among them, especially Gas chromatography equipped with flame ionization detector (GCFID) has high selectivity and, high speed of analysis, accuracy and precision [5].

\section{EXPERIMENTAL METHODS}

\section{a) Materials}

HPLC grade standard substances such as ethanol (Purity$99.98 \%$ and density $\mathrm{d}=0.791 \mathrm{~g} / \mathrm{cm} 3$ ) was purchased from Sigma-Aldrich (USA) and used thereafter without any pretreatment. De-ionized water was obtained from a Thermo Scientific MicroPure ST was used throughout the analysis.

A Palmyrah alcoholic beverage such as toddy was obtained from different Palmyrah societies located in Chavakachcheri, Karaveddi and Kondavil, Jaffna and arrack was obtained from Varany distillery respectively.

\section{b) Instrumentation}

All GC analysis were performed using an Thermo Scientific TRACE 1300 GC System (USA), coupled with a flame ionization detector (FID), equipped with $3 \%$ SP- 1500, 80/120 CARBO PACK B column ( 10 FT x 1/8 IN x 2.1 MM $\mathrm{SS})$. Computer View Sonic, with installed software Xcalibur was used to control GC system and collect chromatographic data. The carrier gas was Nitrogen $\left(\mathrm{N}_{2}\right)$ at 10 psi and splitless injection mode was used. Oven temperature (column temperature) was initially set at $70^{\circ} \mathrm{C}$ and held constant for 2 min and then elevated at the rate of $10^{\circ} \mathrm{C} / \mathrm{min}$ to $180{ }^{\circ} \mathrm{C}$, and held constant for $3 \mathrm{~min}$, thus giving a total run time of $16 \mathrm{~min}$. The injector temperature was held at $200{ }^{\circ} \mathrm{C}$ while the detector temperature was set at $250{ }^{\circ} \mathrm{C}$ and $\mathrm{H}_{2}$ and air at a flow rate of $30 \mathrm{~mL} / \mathrm{min}$ and $300 \mathrm{~mL} / \mathrm{min}$ were used 
ISSN (online): 2581-3048

respectively. The sample injection volume was $0.3 \mu \mathrm{L}$. The samples were injected by direct injection method.

c) GC-FID Method validation and quantitative determination of ethanol

External standard calibration method was used to quantify the ethanol content in Palmyrah alcoholic beverages. Five standard solutions with three replicates $(n=3)$ were prepared from independent dilution to reduce successive dilutions that might be a cause for the accumulation of errors due to sampling preparation. Initially, ethanol standard solution was diluted with de-ionized water to make concentrations of 1,2 , 3, 4 and $5 \% \mathrm{v} / \mathrm{v}$. After mixing, $0.3 \mu \mathrm{L}$ sample solution was injected directly into GC. Peak area of standard ethanol was plotted against ethanol concentration $(\% \mathrm{v} / \mathrm{v})$ to obtain a standard calibration curve.

Palmyrah toddy and arrack samples were homogenized using vortex mixer and filtered through $0.45 \mu \mathrm{m}$ pore sized nylon filter. After mixing, $0.3 \mu \mathrm{L}$ sample solution was injected directly into GC. Ethanol content was calculated according to the standard calibration curve.

\section{d) GC-FID Method validation}

Validation is the confirmation by examination and the provision of objective evidence that the particular requirements for a specific intended use are fulfilled. Calibration curve, linearity, LOD, LOQ, accuracy (recovery), and precision were done in accordance with International Conference on Harmonization (ICH) guideline [6].

\section{i. Calibration curve}

A series of standard ethanol with different concentrations and peak area of ethanol of the standard was used as data variables for ethanol quantification in this study.

\section{ii. Linearity}

Linearity of any analytical method is the ability to obtain directly proportional test results of variable data against the different concentration. Linearity was evaluated by using calibration curve to calculate coefficient of correlation $\left(\mathrm{r}^{2}\right)$ and intercept values.

\section{iii. Limit of detection (LOD) and the limit of quantification (LOQ)}

LOD is the lowest amount/value/ concentration of analyte in a sample that can be detected and identified by the procedure while LOQ is the lowest amount of analyte in a sample which can be quantitatively determined with suitable precision and accuracy. LOD and LOQ were calculated using equations A and $\mathrm{B}$ where $\mathrm{s}$ is the standard deviation of intercept, and is a slope estimated from the calibration curve of the analyte.

$\mathrm{LOD}=3.3 \mathrm{~s} / \mathrm{a}($ Equation $\mathrm{A})$

$\mathrm{LOQ}=10 \mathrm{~s} / \mathrm{a}($ Equation $\mathrm{B})$

\section{iv. Precision}

Precision was measured under the same operating conditions of analytical method over a short interval of time, together with the same equipment. The precision test was carried out in a minimum of six determinations and expressed in coefficient of variation, $\mathrm{CV} \%$.

\section{RESULTS AND DISCUSSIONS}

Figure 1-3 show typical chromatograms obtained from ethanol standard, Palmyrah toddy and Palmyrah arrack samples respectively analyzed following the conditions reported above.



Figure 1: Chromatogram of ethanol standard solution

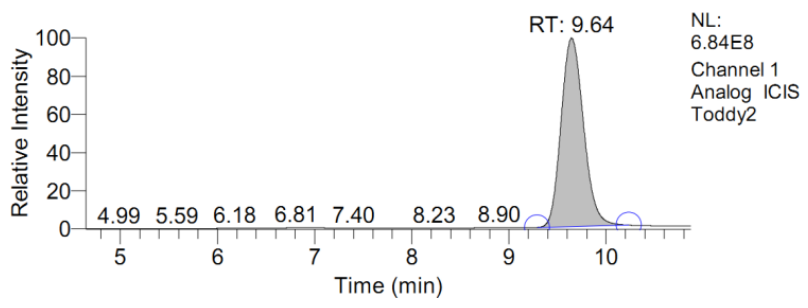

Figure 2: Chromatogram of Palmyrah toddy sample

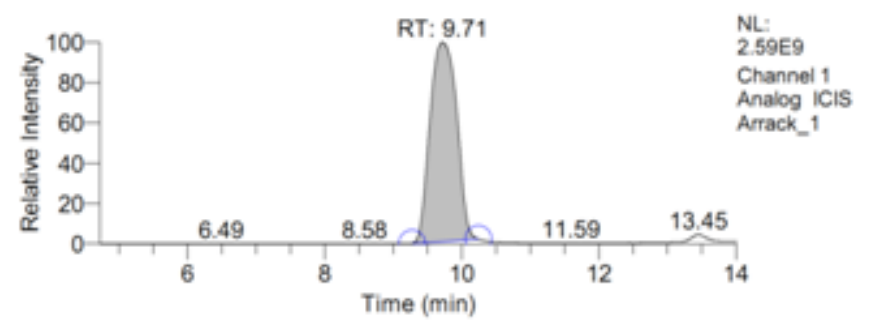

Figure 3: Chromatogram of Palmyrah arrack sample

According to that, retention time of ethanol standard solution was 9.63 min. Peak of Palmyrah toddy and arrack sample was detected at $9.63 \mathrm{~min}$ and 9.71 which were confirmed the presence of ethanol. 
ISSN (online): 2581-3048

Volume 5, Issue 5, pp 101-104, May-2021 https://doi.org/10.47001/IRJIET/2021.505019

External standard calibration was performed by analyzing the five standard calibration solutions, and plotting the ethanol contents vs. the respective peak areas. Figure 4 shows the calibration function calculated using linear regression. The correlation coefficient (R2) for this calibration was 0.9999, demonstrating excellent linearity for this method. Hence the liner range of this method is $1-5 \% \mathrm{v} / \mathrm{v}$. The standard error of the intercept and standard deviation of the intercept are 0.162 $\%$ and 0.058 respectively. Using these data, obtained LOD and LOQ for the calibration data of ethanol were 0.067 and 0.188 $\% \mathrm{v} / \mathrm{v}$ respectively. Table 01 shows the percentage of recovery and precision of ethanol standard solutions.

According the results standard deviation of the ethanol standards was in the range of 0.008 to $0.143 \%$ and relative standard deviation of the calibration graph is $0.058 \%$. Recovery of the ethanol standards was in the range of 98.453 to $101.833 \%$.

The ethanol content (\% v/v) and precision of Palmyrah alcoholic beverages were shown in Table 02. Ethanol content of toddy samples from different locations was quantified within the range of 5.23034 to $6.2018 \%$ (v/v) in the while ethanol content of arrack was quantified as $31.3339 \%(\mathrm{v} / \mathrm{v})$. The precision, which was expressed in coefficient variation, was in the range of 0.8483 to $8.0116 \%$. It can be concluded that the concentration of toddy is usually about 3-6\% v/v and arrack is about $30-35 \% \mathrm{v} / \mathrm{v}$.



Ethanol standard concentration (\% v/v)

Figure 4: Calibration graph of ethanol standard solutions

Table 1: Results obtained for calibration curve of ethanol

\begin{tabular}{cccccc}
\hline $\begin{array}{c}\text { Ethanol standard } \\
\text { concentration }(\% \mathbf{v} / \mathbf{v})\end{array}$ & $\begin{array}{c}\text { Average Area of } \\
\text { peak x 10 }\end{array}$ & $\begin{array}{c}\text { Found } \\
\text { concentration }\end{array}$ & Recovery (\%) & $\begin{array}{c}\text { Standard } \\
\text { deviation } \\
(\mathbf{n}=6)\end{array}$ & Precision (CV \%) \\
\hline 1 & 3.881853111 & 0.9845397 & 98.45397 & 0.008665 & 0.223214 \\
\hline 2 & 7.634808149 & 2.036671755 & 101.8336 & 0.052517 & 0.687862 \\
\hline 3 & 10.91614263 & 2.956586104 & 98.55287 & 0.029527 & 0.27049 \\
\hline 4 & 14.79191461 & 4.043149597 & 101.0787 & 0.056422 & 0.381439 \\
\hline 5 & 18.14041009 & 4.981892371 & 99.63785 & 0.143434 & 0.790688 \\
\hline
\end{tabular}

Table 2: Percentage precision values for ethanol in Palmyrah alcoholic samples

\begin{tabular}{cccc}
\hline Palmyrah Alcoholic beverage & Location & Ethanol content $(\%)$ & Precision $($ CV \%) \\
\hline \multirow{2}{*}{ Toddy } & Chavakachcheri & $5.7075 \pm 0.43442$ & 7.6114 \\
\cline { 2 - 4 } & Karaveddi & $6.2018 \pm 0.4968$ & 8.0116 \\
\cline { 2 - 4 } & Kondavil & $5.2034 \pm 0.0441$ & 0.8483 \\
\hline Arrack & Varany & $31.3339 \pm 1.9422$ & 1.9423 \\
\hline
\end{tabular}


ISSN (online): 2581-3048

\section{CONCLUSION}

A GC-FID method was developed for analysis of ethanol content in Palmyrah toddy and arrack. Ethanol content was determined using packed column with a total run time of 14 min. The sample preparation procedure was simple and straightforward with no derivatization required. The method was validated and proved to be specific, precise and accurate for analysis of ethanol. Hence, exploitation of such validated method may keep the degree of user confidence regarding their analytical data.

\section{ACKNOWLEDGEMENT}

The authors gratefully acknowledge the research facilities provided by Palmyrah Research Institute, Palmyrah Development Board, Kaithady, Jaffna, Sri Lanka.

\section{REFERENCES}

[1] SUNDARESAN, R. and KANAGASUNDARAM, S., Chemical Analysis of Palmyrah Palm (Borassus flabellifer L.) Wine.

[2] Fernando K , Fernando R, Kandasami A, Jude R, Fernando N, Tennakoon S, "SP6-3 Fermented sap of spiky Palmyra toddy (Borassus flabellifer) suggested as a vehicle of transportation of amoebiasis in the district of Mannar, Sri Lanka: 50 cases of amoebic liver abscess within 15 months", Journal of Epidemiology \& Community Health 65(Suppl 1): pp.A455-A455, 2011.

[3] Vengaiah PC, Murthy GN, Sattiraju M, Maheswarappa HP, "Value Added Food Products from Palmyra Palm (Borassus flabellifer L.)", Journal of Nutrition and Health Science 4(1): pp.1-3, 2017.
[4] Wang ML, Choong YM, Su NW, Lee MH, “A rapid method for determination of ethanol in alcoholic beverages using capillary gas chromatography", Journal of Food and Drug Analysis 11(2), 2003.

[5] 4. Tonelli D, "Methods for determining ethanol in beer. In Beer in Health and Disease Prevention (pp. 1055-1065)", Academic Press, 2009.

[6] ICH harmonized tripartite guideline: validation ofanalytical procedures: text and methodology Q2(R1), International Conference of harmonization of technical requirements for registration of pharmaceuticals for human use 2005.

\section{AUTHOR'S BIOGRAPHY}

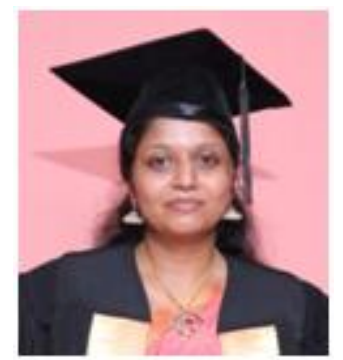

A. Kirushanthi, Working as a Research Assistant at Palmyrah Research Institute (PRI), In charge of the High- Tech Laboratory at PRI, Reading M.Phil, and Completed B.Tech. (Hons.) Materials Science (Sp.)

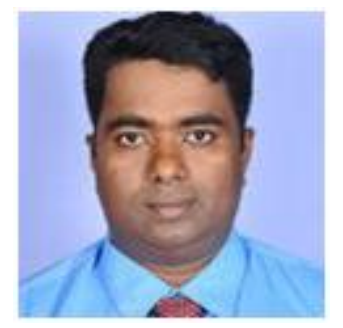

S. Srivijeindran, Manager (Applied Research and Quality control) at PRI, Reading Doctoral degree

Completed B.Sc (Special in Chemistry), M.Sc (Industrial Analytical Chemistry), Chartered Chemist (C.Chem), M.A (Administration) and PgD.MM (Manufacturing)

\section{Citation of this Article:}

A. Kirushanthi, S. Srivijeindran, "Validation of an Analytical Method using GC-FID to Determine the Ethanol in Palmyrah Alcoholic Beverages" Published in International Research Journal of Innovations in Engineering and Technology - IRJIET, Volume 5, Issue 5, pp 101-104, May 2021. Article DOI https://doi.org/10.47001/IRJIET/2021.505019 